\title{
The nature of the law's fulfilment in Matthew 5:17: An exegetical and theological study
}

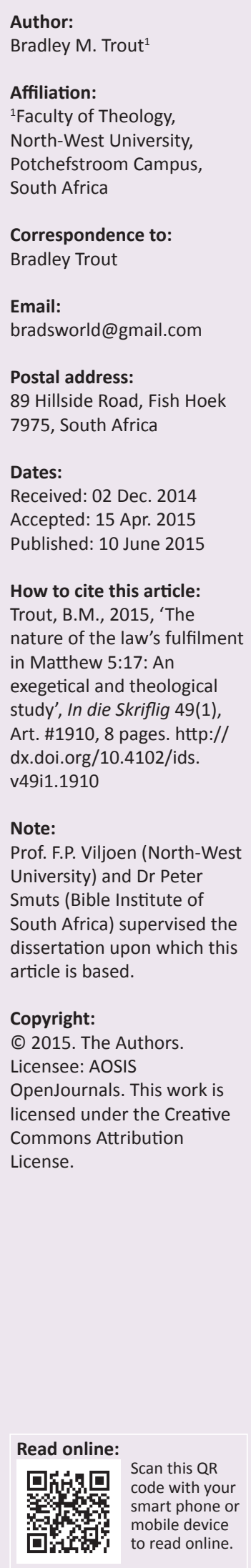

The relationship between law and gospel remains something of a conundrum for biblical scholarship. Matthew 5:17, and in particular what is meant by Jesus' having come to fulfil the law and the prophets, contributes significantly to this ongoing discussion. What precisely is meant by 'to fulfil the law and the prophets' is an exegetical enigma. Utilising an eclectic array of methods, including literary, historical and theological approaches, this article attempts to articulate the nature of fulfilment in Matthew 5:17. In addition to arguments made on the basis of historical-critical exegesis, including the discussion of the nature of $\pi \lambda \eta \rho$ ó $\omega$ in Matthew's Gospel, the sense in which the law prophesies and the contribution of the so-called antitheses of 5:21-48, we argue that the biblical-theological theme of the Kingdom of God clarifies a salvation-historical reading of Matthew 5:17. When it is said that Jesus has come to fulfil the law and the prophets, an eschatological or salvation-historical reading shows that what the law pointed towards has arrived in the teaching and ministry of Jesus. A biblical-theological reading of the Kingdom of God helps us, however, to add a measure of precision to this statement. Jesus fulfils the law and the prophets by bringing into being what was anticipated. The law and prophets anticipated the arrival of the Kingdom of God. Fulfilment, then, should be construed in terms of this motif. Jesus fulfils the law and the prophets by inaugurating the Kingdom of God to which they pointed. This renders discussion over whether Jesus fulfils the law and the prophets through either his teaching or his activity unnecessary, since the Kingdom of God is inaugurated through both.

Die Aard van die Vervulling van die Wet in Matteus 5:17: 'n Eksegetiese en Teologiese Studie. Die verhouding tussen die wet en die evangelie bly in ' $n$ mate raaiselagtig ten opsigte van die bybelse wetenskap. Matteus 5:17, en veral die bedoeling van Jesus se koms om die wet en die profete te vervul, dra aansienlik by tot hierdie deurlopende bespreking. Wat presies bedoel word met 'om die wet en die profete te vervul', is 'n eksegetiese raaisel. Deur gebruik te maak van 'n eklektiese verskeidenheid van metodes wat literêre, historiese en teologiese benaderings insluit, poog hierdie artikel om die aard van die vervulling in Matteus 5:17 duidelik te omskryf. Benewens die gewone argumente, onder andere die bespreking van die aard van $\pi \lambda \eta \rho$ ó $\omega$ in die Matteusevangelie, die profetiese mag van die wet en die bydrae van die sogenaamde teenstellings van Matteus 5:21-48 wat op die basis van histories-kritiese eksegese geopper word, word aangevoer dat die bybels-teologiese tema van die koninkryk van God die heilshistoriese lesing van Matteus 5:17 verskerp. Wanneer beweer word dat Jesus gekom het om die wet en die profete te vervul, bewys 'n eskatologiese of saligheid-historiese verstaan daarvan dat dít waarna die wet heengewys het, vervul is deur die onderrig en bediening van Jesus. 'n Bybels-teologiese verstaan van die Koninkryk van God help ons om hierdie stelling met meer noukeurigheid waar te neem. Jesus vervul die wet en die profete deur die verwagting van die koms van die Koninkryk van God te volvoer. Vervulling moet dus in terme van hierdie motief vertolk word. Jesus vervul die wet en die profete deur die vestiging van die Koninkryk van God waarna die wet en profete heenwys. Dit maak die debat oor die kwessie of dit Jesus se onderrig of sy werking was wat die wet en die profete vervul het, onnodig, omdat die Koninkryk van God deur albei gevestig is.

\section{Introduction}

I was introduced to the law and gospel debate some years ago when reading, of all things, a newspaper comic. In this strip, the renowned South African political cartoonist, Zapiro, depicts the minister of the African Christian Democratic Party, declaring that homosexual marriage runs contrary to God's Word (Shapiro 2007:25). Following this the cartoonist proceeds to ask him some questions regarding the Bible: 'If I sell my daughter into slavery as allowed in Exodus 21:7, what in this day would be a fair price for her?' Also, 'I have had my hair cut, even round the temples, 
though Lev. 19:27 forbids this. Can I get exemption from stoning?'

Apparently Zapiro's point is that the Bible contains many laws that we can no longer keep. I do not wish to make any point from this strip other than to underscore the practical relevance of how we understand the law's continuity and discontinuity, not least in 21st century South African ethics.

In the world of biblical studies, this discussion continues in every field: the Old Testament's view of the law, Paul's view of the law, and Jesus' view of the law. Regarding the latter, Meier (2009:2) has recently observed: 'in the past century almost every position imaginable has been defended in the attempt to understand Jesus' position, vis-à-vis the Mosaic law'.

When Matthew's view of the law is examined, one finds similar diversity. Snodgrass (1992:368) has spoken of Matthew's statements on the law as seeming to 'defy understanding', and scholarship on the question as 'a virtual circus of views'. Within the many passages relevant to the discussion, Matthew 5:17-20 is of central significance. Deines (2008:70) has referred to this passage 'as a kind of hermeneutical introduction to the Matthean theology of the law'. The questions asked of this passage are no less contentious. Is the focus of this section didactic or eschatological? How do we reconcile the prophetic and legal elements in 5:17? Should 3:15 or the formula quotations govern our interpretation of fulfilment in 5:17? Each of these comes down to what Matthew means by 'to fulfil'. This article will therefore address specifically the question: What does it mean that Jesus fulfils the law?

Two developments in the world of biblical studies over recent decades need to be brought to bear on the discussion of the meaning of $\pi \lambda \eta \rho$ ó $\omega$ : the advance of both literary approaches and biblical theology. In addition to regular historical critical exegesis, both have bearing on the present question and may aid one in understanding more precisely what it means to say that Jesus fulfils the law. This article begins by examining some previous contributions to understanding Matthew 5:17, and then proceeds to literary, historical-grammatical and theological considerations.

\section{Previous scholarship}

A great deal has been written on $\pi \lambda \eta \rho$ ó $\omega$ over the last 100 years and no attempt is made to summarise it all. ${ }^{1}$ What is attempted here is a simple delineation of five prominent ways the concept of fulfilment in Matthew 5:17 is understood today.

\section{Fulfil as uphold}

Scholars such as Wenham (1979), Charles (2002) and Loader (2002) have argued that 'to fulfil' should be understood in the sense of the law being 'upheld' or 'confirmed'. This, they

1.A useful taxonomy of views prior to 1988 is provided by Davies and Allison (1988:484-487; cf. Carter 1994:84-88). argue, makes the most sense of the contrast between $\pi \lambda \eta \rho$ ó $\omega$ and $\kappa \alpha \tau \alpha \lambda \dot{\omega} \omega$ in 5:17. Furthermore, it makes the most sense of the probable historical context in which Jesus is being charged as a lawbreaker. Against this charge Jesus affirms the eternal validity of the law. Moreover, Charles (2002:8) argues that the literary context, which includes good works (5:16) and 'better righteousness' (5:20), is favourable to this interpretation.

\section{Fulfil as Jesus' obedience}

Another view of $\pi \lambda \eta \rho$ ó $\omega$, espoused by Luz (1989) some years ago, and more recently by Ross ${ }^{2}$ (2010) and Chantry (2008), understands the term to refer to Jesus' obedience. For Luz

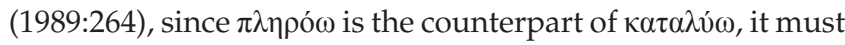
focus more on Jesus' deeds than on his teaching. Luz thinks that $\kappa \alpha \tau \alpha \lambda v \omega$ suggests that Jesus' obedient practice is in view. Furthermore, Luz suggests that the uses of $\pi \lambda \eta \rho$ ó $\omega$ in both the 'fulfilment formulas' and in 3:15, also has Jesus' actions in view. Therefore, Jesus fulfils the demands of the law and prophets through his obedience, that is, Jesus keeps the law (Luz 1989:261). Chantry (2008:58), a reformed interpreter, adds that, since 3:18 refers to what is to be accomplished, we are to view the concept of fulfilment in verse 17 as relating to what is done. In this view, then, it is Jesus' actions that bring fulfilment to the law and the prophets.

\section{Fulfil as the realisation of the law's intended meaning or new depth of insight}

A third view understands 'to fulfil' to be referring to Jesus as the one who brings out the intended meaning of the law. This is the view put forward by Hagner (1993). This view takes 'to fulfil' as referring to Jesus' teaching as to 'establish' or 'complete' it. Jesus thus brings out the true meaning of the law through definitive interpretation. This interpretation both holds together the emphasis on the law's continuity in 3:18 and affirms an element of newness in light of fulfilment.

A related but somewhat nuanced version of this view has recently been put forward by Nolland (2005), who thinks that to fulfil must focus on what Jesus does as a teacher. Nolland bases his understanding on the antitheses in which Jesus displays a new depth of insight into what the law requires. Jesus is then enabling his disciples to live out the law by more clearly explaining its essential demands. This is similar to Hagner's view, except that Nolland adds a note of advance to his articulation of fulfilment (cf. Dunn 2013:514).

\section{Fulfil as transcend}

Westerholm (1992; cf. Davies \& Allison 1988:486) has argued for a transcending sense to $\pi \lambda \eta \rho$ ó $\omega$ in this verse. This understanding is largely based (again!) on the antitheses of Matthew 5:21-48, in which the law is not abolished, but transcended. Matthew is insisting, argues Westerholm

2.Ross' view (2010:214) is more nuanced. He believes that, in addition to fulfilling the
law and the prophets by his obedience, Jesus does so in his person and teaching, law and the prophets by his obedience,
and by making his followers obedient. 
(1992:47), that Jesus' demands do not lead to abandoning the law, but rather his teaching transcends them by being a more perfect picture of the nature of God's will. Each of the six antitheses shows that Jesus' commands 'transcend the law by prescribing the goodness of God as the standard for his children' (Westerholm 1992:56).

\section{Fulfil as the realisation of what the law anticipated}

Many scholars, following Banks (1975), have taken what may be termed as the 'eschatological' or 'prophetic' view of $\pi \lambda \eta \rho o ́ \omega$ in 5:17 (cf. Deines 2008; France 2007; Meier 1991; Moo 1984; Thielman 1999; Turner 2008). In this view, the meaning of 'to fulfil' follows Matthew's regular use of the verb in which what was anticipated, has now been realised. Furthermore, Matthew 11:13 shows that the law itself carries a prophetic function in Matthew's mind. Therefore, what both the law and the prophets predicted, has been brought into being by Jesus.

Space forbids an evaluation each of these views here. This article finds the fifth view, namely that the law and prophets are fulfilled through the realisation of what was anticipated, to be the most satisfying overall, whilst not precluding other senses. However, since there is still no consensus on the matter, it is worth reinvestigating the evidence. This will be done by bringing literary, exegetical and biblicaltheological considerations to bear on the interpretation of 'fulfilment'.

\section{Contextual consideration}

\section{Literary}

1. Structure: In response to the topical outline of Kingsbury (1989:36), France (2007:4) has proposed a geographical outline of Matthew's Gospel. In this structure, Jesus' ministry is presented in three phases: Galilee, the journey from Galilee to Judea, and Jerusalem. France contends that this outline provides a better basis for discerning Matthew's narrative structure than the search for verbal divisions. ${ }^{3}$ If one adopts France's proposed structure, the Sermon on the Mount, and especially 5:17-20, are placed in the initial Galilean stage of Jesus' ministry (4:12-16:20) in which his authority is being revealed in his teachings (Mt 5-7) and his actions (Mt 8-9). If the entire section is developed around demonstrating the Messiah's authority as 7:28-29 certainly suggests, this supports the contention of those who advocate an eschatological reading of $\pi \lambda \eta \rho o ́ \omega$ in 5:17 that it is Jesus rather than the law who is the focus of this section (cf. Banks 1975:226).

2. Plot: Wright has laboured to show that the gospels have the story of Israel as their backdrop. The basic Jewish hope, Wright (1992:299) argues, was for liberation from oppression, restoration of the land, and the rebuilding

3.My purpose here is not to argue for this structure above other proposals which have equal merit. I wish rather to point out the insights this structure yields to the question at hand. of the temple. Building on the work of Powell (1992), Wright (1992:385) points out that Matthew's Gospel shows not only how the forgiveness mentioned in 1:21 is accomplished, but presupposes a previous story, namely that of Israel in exile. In short, Wright has shown that, when considering Matthew's plot, we must do so in the context of Israel's history and expectation, which has bearing on Matthew's notion of 'fulfilment'. When Jesus declares that he has come, not to abolish, but to fulfil the law and the prophets, he is speaking to a people who are longing for the fulfilment of the Old Testament's hope. When Jesus' statement is situated within the larger plot of Matthew's Gospel, the sense that, what the law and prophets anticipated, has now arrived in the Messiah, becomes clearer.

3. The Sermon on the Mount: There have been many proposals for the Sermon's purpose, namely characterformative: 'the Sermon on the Mount functions primarily as a catalyst for the formation of character. (Talbert 2004:29); inspirational: 'The Sermon's primary purpose is to instill principles and qualities through a vivid inspiration of the moral imagination' (Allison 1999:11); ethical: 'the sermon amounts to personal ethics for followers of Jesus ... The Sermon on the Mount is Jesus' authoritative teaching about the way believers should live today' (Turner 2008:144); Christological: 'far from being a philosophical discourse on ethics, this is a messianic manifesto, setting out the unique demands and revolutionary insights of one who claims an absolute authority over other people and whose word ... will determine their destiny' (France 2007:156). When one considers the emphasis on what Jesus says as binding on his followers (Moo 1999:350), the response of the crowds at the conclusion of the Sermon (Moo 1984:23), and Jesus' assumption that 'he himself is the proper object of people's allegiance and the arbiter of their destiny' (France 2007:297-299), there is strong support for those (e.g. Banks 1975; Davies 1966; France 2007:299) who argue that the Sermon essentially presents us with the one who utters words with such authority. Jesus' claim to fulfil the law and the prophets by bringing to realisation what they anticipated, fits well with this focus on his authority.

\section{The antitheses}

Many interpretations of 5:17 depend on a particular interpretation of the antitheses of 5:21-48, since they illustrate the nature of the fulfilment Jesus brings. These contrasts are generally understood in one of three ways: firstly, Jesus is stating the true intention or interpretation of the law (cf. Hagner 1993:111; Talbert 2004:68; Turner 2008:158); secondly, Jesus is deepening the law (cf. Hill 1978:119; Sanders 1993:210); or thirdly, Jesus' divine authority over against the law is being demonstrated. Here the emphasis is on what Jesus says. That this had an effect on the crowds is seen by their response at the end of the Sermon (7:28-29). The whole discourse, France (2007:199) says, is characterised as of unparalleled authority. This view does not preclude the 
other senses; it only argues that the unifying factor in each of the six contrasts is their demonstration of the Messiah's authority:

1. How does this understanding of the antitheses bear on our interpretation of 5:17:

2. Since the antitheses point to the authority of Jesus, it is to him that the disciples have to look for a definitive statement of the law.

3. Jesus' teaching does not oppose the law; rather 'fulfilment' suggests that Jesus' demands surpass the demands of Torah without contradicting it (Davies \& Allison 1988:508).

4. A fulfilled law is exhibited by an inward righteousness that exemplifies God's character and loves others; this is righteousness that exceeds the righteousness of the Scribes and Pharisees.

Frank Thielman (1999:51ff.) has helpfully shown the sense in which the antitheses illustrate fulfilment: 'The antitheses illustrate how Jesus' ethical teaching identifies the prophetic element in the Mosaic law and fulfils the law's "prophecy" by bringing it to completion.'

Jesus' teaching replaces the standing command with the goal to which it pointed. If obeyed, Jesus' teaching would make the Mosaic legislation unnecessary. This is how the law is fulfilled. Thielman has made a helpful contribution towards understanding the relationship between $\pi \lambda \eta \rho$ ó $\omega$ in its eschatological sense and the antitheses. If the antitheses represent the ethical goal to which the law pointed, it is likely that $\pi \lambda \eta \rho$ ó $\omega$ in 5:17 ought to be understood correspondingly.

\section{Kingdom of God in Matthew}

It is generally agreed that the Kingdom of God was at the centre of Jesus' message and ministry (cf. Farmer 1987:126; Pennington 2008:44). Jesus' announcement in 5:17 is found within the context of the announcement of God's Kingdom $(4: 17,23)$. The phrase means 'that God is about to put things right and establish his righteous rule on earth' (Westerholm 2006:81). By and large, this concept summarises the Jewish expectation, which was mentioned earlier. Foundational to both the Old Testament and other Jewish writings was the expectation that God would act in such a way as to vindicate his people through the coming of his Kingdom. Wright (1992) summarises the hope of Israel:

Most were hoping, some fervently, for a new turn in Israel's fortunes. If there is a one creator god ... then this god must act sooner or later to restore (Israel's) fortunes. Israel is still in a state of 'exile', and this must be put right. (p. 281)

For Wright (1992:302), 'Kingdom of God' basically expresses the hope that Israel's God would act to restore her fortunes. Other scholars of both the Old and New Testaments have also expressed Israel's expectation in terms of the Kingdom of God (cf. Beasley-Murray 1992:19; France 2007:102; Waltke 2012:61; Yarbrough 2012:107).
The concept of the Kingdom of God or heaven ${ }^{4}$ is central to Matthew's theology, with $\beta \alpha \sigma \imath \lambda \varepsilon i ́ \alpha$ occurring some 55 times,

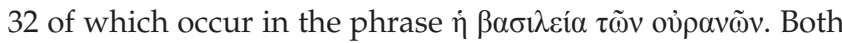
Westerholm (1992:44) and Deines (2008:71ff.) have noticed the importance of the Kingdom in understanding Matthew 5:17 and the law. Since something new has been inaugurated and the decisive stage of God's dealings with his people has begun, any discussion of Jesus and the law must be placed into this context. Westerholm (1992:46ff.) makes several points regarding Matthew's portrayal of Jesus' proclamation of the kingdom, noting that Jesus' coming means the culmination of salvation-history. The kingdom is the dawning of God's eschatological rule, and it is in this context that Jesus' relationship to the law needs to be understood. When seen in this light, departures from some standards of the law are understandable: Jesus proclaims a kingdom righteousness that does not fall short of Moses' demands, but rather transcends them as 'a more perfect embodiment of the divine will’ (Westerholm 1992:47).

This context of the dawning of God's reign in the person and ministry of Jesus is significant for understanding of Matthew $5: 17$, because it makes interpretations to the effect that the law is merely 'established' unlikely. There has been a dramatic shift in the history of God's dealings with his people; a shift that has implications for the law and the prophets. When considered in this light, a salvation-historical explanation of 'fulfil' in Matthew 5:17 makes the most sense of the larger story within which Matthew places Jesus.

\section{Fulfilment in Matthew}

One final context in which to evaluate the various ways $\pi \lambda \eta \rho$ ó $\omega$ in 5:17 has been understood is Matthew's concept of 'fulfilment'. The use of the verb $\pi \lambda \eta \rho$ ó $\omega$ is characteristic of Matthew's Gospel, being employed no fewer than 16 times (1:22; 2:15, 17, 23; 3:15; 4:14; 5:17; 8:17; 12:17; 13:35, 48; 21:4; $23: 32 ; 26: 54,56 ; 27: 9)$, most of which are unique to Matthew. These and other considerations have led France (1989:166) to call 'fulfilment' 'the central focus of (Matthew's) theology'. The clause 'to fulfill what had been spoken by the prophet, saying ... 'introduces 10 references to the Old Testament (1:22-23; 2:15; 2:17-18; 2:23; 4:14-16; 8:17; 12:17-21; 13:35; $21: 4-5 ; 27: 9-10$. In each instance the formula indicates that a trajectory set by the original context has reached its culmination in Jesus. What the events in the law and prophets foreshadowed has arrived in Jesus' ministry.

\footnotetext{
4.Most scholars have assumed "kingdom of heaven' to be the equivalent of 'kingdom of God' (Davies \& Allison 1988:390) on the grounds that Matthew wants to avoid using God's name: "'Kingdom of heaven" is a distinctively Matthean expression for the kingdom of God. There is little doubt that Matthew uses it in order to avoid mentioning the name of God' (Turner 2008:107). This notion has been seriously challenged in recent years, most notably by Pennington (2008:45): 'this reverential circumlocution explanation for Matthew's "kingdom of heaven" proves indefensible'. As evidence Pennington cites the fact that Matthew does, in fact, employ the phrase

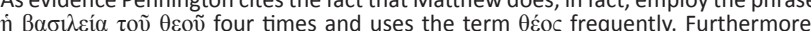

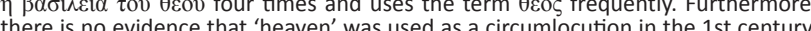
there is no evidence that 'heaven' was used as a circumlocution in the 1st century. Pennington argues these and other points at length in his book Heaven and Earth in the Gospel of Matthew (2007:19-37). Having noted this difference, for the duration of this article, the phrases will be used interchangeably, since 'Kingdom of heaven' is very often Matthew's version of Mark's 'Kingdom of God'. Although, it is acknowledged, following Pennington (2008:46), that Matthew's particular slant on the phrase 'kingdom of heaven' is but one part of an elaborate theme of 'heaven and earth' woven all throughout the first gospel'.
} 
Three things may be said about Matthew's use of 'fulfilment' language. Firstly, when Matthew records that what a certain prophet said was fulfilled, he is probably referring to the culmination of a pattern represented by a certain event in the past (cf. Turner 2008:22). Secondly, despite the difficulty in pinning down its meaning, typology - understood as earlier events establishing patterns, which anticipate God's actions in future events - helps us to understand how the Old Testament points to Jesus in ways beyond mere prediction (cf. Blomberg 2002:19ff.; France 1989:185ff.). Understanding Old Testament typology in this manner squares with a salvation-historical ${ }^{5}$ reading of Matthew 5:17 where it is likely that the use of $\pi \lambda \eta \rho$ ó $\omega$ carries a similar meaning. Thirdly, Kirk's recent argument (2008:77ff.) that we should conceptualise 'fulfilment' by seeing Jesus as re-enacting the story of Israel as plotted in the law and prophets, has implications for our understanding of Matthew 5:17. When we see Jesus fulfilling Israel's story by embodying and reenacting it, we see that in this passage Jesus is replaying the law-giving moment in Israel's story (Kirk 2008:96). This in turn enables us to understand the manner in which Jesus fills up the Old Testament story. This takes the focus away from the law as such and places it on Jesus, the one to whom the original story of the law pointed. These three considerations show that Matthew's concept of fulfilment has a salvationhistorical flavour in which what happened in Israel's history, anticipated the actions displayed in Jesus' ministry. This sense most likely also colours Matthew's usage in 5:17.

\section{Further exegetical considerations}

It is necessary to focus particularly on the passage as it stands in 5:17-20.

What one finds in 5:17-20 are the general principles, which are then illustrated by the antitheses of 5:21-48 (France 2007:178; Keener 2009:175; Thielman 1999:52; Turner 2008:161). Furthermore, this passage anticipates objections to what the antitheses appear to teach (Davies \& Allison 1988:481; Hagner 1993:103; Nolland 2005:216). Here the following question is answered: What does the coming of God's Kingdom in Jesus mean for the Jewish Scriptures? By framing the question in this way, rather than simply speaking of 'Jesus' relationship to the law, one takes better cognisance of this passage's place in Matthew's larger narrative.

\section{The law and the prophets}

The inclusion of 'the prophets' alongside the law is significant, especially since it is the law that takes centre stage throughout the rest of the passage. ${ }^{6}$ Matthew probably includes both,

5.The loaded concept of 'salvation history' has been understood in several ways. Here Eloff's 'temporal' definition (2008:87) from his recent essay on salvation-history in Matthew is followed: 'salvation history (is) the temporal-theological aspect of Matthew's ideological point of view'. Cf also, Rosner (2005.714), where 'salvation history' is understood as 'redemptive history'. According to Rosner, salvation history history' is understood as 'redemptive history.' According to Rosner, salvation history Bible unfold the narrative of these events.

6.Viljoen (2011:394) notes that, of the eight occurrences of $\dot{o}$ vó $\mu$ oc in Matthew, four

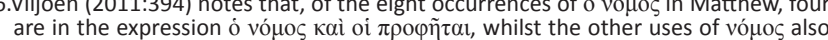

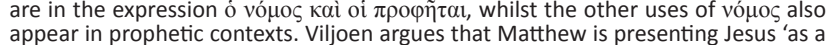
appear in prophetic contexts. Viljoen argues that Matthew is p
prophet who gives the authoritative interpretation of the law'. because God's will is laid out by the law and the prophets, and also because it introduces the concept of fulfilment: Jesus fulfils God's entire revelation (Hagner 1993:105). Both the law and the prophets predicted the coming age of the Kingdom of God. Thus, in Jesus both are fulfilled.

\section{Meaning of $\pi \lambda \eta \rho o ́ \omega$}

Arndt, Danker and Bauer (2000) list $\pi \lambda \eta \rho \omega^{\prime} \omega$ as it is found in Matthew5:17 under 'to bring to a designed end', but add that the precise meaning depends on how one interprets the context. Other lexical studies are equally inconclusive (cf. Kittel \& Friedrich 1963; Louw \& Nida 1996).

Therefore, it is to the context that one must turn. As discussed above, Matthew's formula quotations provide what might be called a salvation-historical understanding of $\pi \lambda \eta \rho o ́ \omega$ in which Matthew sees an event, which transpired in the Old Testament as it has reached its historical climax in Jesus. In this sense, then, 'fulfil' means that the trajectory, which was set in motion by a particular Old Testament event, has now reached its conclusion. Furthermore, the use in Matthew 3:15 - also in the aorist active infinitive - probably refers to Jesus' fulfilling of prophecy, since prophecy is in focus in virtually all of Matthew's other references to $\pi \lambda \eta \rho$ ó $\omega$. Moreover, the allusions to the Old Testament imply the realisation of scriptural hopes (cf. Ps 2:7; Is 42:1; Davies \& Allison 1988:326). In short, both the formula quotations and Matthew 3:15 connote a sense of bringing into being that which was anticipated in the Old Testament. This would therefore also be the most logical way to understand the term in Matthew 5:17.

\section{Matthew 11:13}

In what sense does the law prophesy? Matthew 11:13 shows that Matthew certainly conceived of both prophets and law as having prophetic functions. Here salvation history is in view. What the Jewish scriptures - the law and the prophets - pointed toward has arrived in the ministry of John the Baptist. The sense in 5:17 is similar: not only the prophets, but also the law prophesied or pointed forward to the fuller revelation of God's will that came with the time of fulfilment in Jesus' ministry (France 2007:431). It is in this sense that Jesus fulfils the law and the prophets (cf. Deines 2008:83).

This section has considered several factors from the literary context and surveyed some of the standard arguments for a prophetic reading of Matthew 5:17. Finally, it needs to be considered how biblical theology may be brought to bear on this interpretation.

\section{Theological considerations}

Despite resistance to the idea of a unified biblical theology (cf. Bartholomew 2005:86), several attempts have been made to construe an overarching theme or metanarrative or theology of the Bible (cf. Childs 1992; Scobie 2003). 
One theme that has immerged consistently as central to the biblical narrative is that of the Kingdom of God.

\section{The Kingdom of God}

Several biblical theologians have paid attention to the prominence of this theme from a biblical theological perspective. Goldsworthy (2012:75), for instance, refers to the Kingdom of God as the central theme in Scripture. Scobie (2003:106) also refers to the Kingdom of God as 'a central biblical theme'. Bartholomew and Goheen (2004:24ff.) structure their Drama of Scripture around the idea of 'Kingdom'. Similarly, Gentry and Wellum (2012:24) have recently proposed 'kingdom through covenant' as the central concept in mapping the narrative structure of Scripture. All these echo Ridderbos' earlier declaration (1962:xi) that 'in Jesus Christ's proclamation of the kingdom we are face to face with the specific form of expression of the whole of his revelation of God'. Old Testament theologian, Bruce Waltke (2007:144), has referred to the coming of God's kingship as the concept which 'best accommodates all of the blocks of writing in the Old Testament'. Regarding the New Testament, Yarbrough (2012:100) has recently written: 'we could conceivably array all of biblical theology along an axis entitled "kingdom of God"'. It is beyond the scope of this article to evaluate the extent to which these scholars accurately portray the theology of the Old and New Testaments as well as their relationship. The point is merely to show that many have recognised the Kingdom of God as a central theme of the Christian Scriptures. What some practitioners of biblical theology have given us, then, is an appreciation of an overarching metanarrative of Scripture, which finds the Kingdom of God as a central theme (cf. Beale 2011:19; Köstenburger 2012:10).

What bearing, if any, does this have on Matthew 5:17? Above it was shown that many studies have recognised the Kingdom of God to be a central theme throughout the biblical narrative. Earlier it was established that the Kingdom of God or heaven is a central theme in Matthew's Gospel. If one brings these two considerations to bear on Matthew 5:17 it might be argued that, given Matthew's desire to show that in Jesus the Scriptures have found their fulfilment - he is the one to whom they pointed - and given that the Scriptures point to the arrival of the Kingdom of God, the concept of fulfilment should be construed by this overarching motif. This would give fulfilment in Matthew 5:17 the meaning that, what the law and the prophets pointed towards, namely the arrival of God's Kingdom, has now come about in Jesus. Fulfilment means that the kingdom has come. Such an understanding of $\pi \lambda \eta \rho$ ó $\omega$ in Matthew 5:17 has the benefit of placing this pericope not only in the context of Jesus' Sermon on the Mount and the context of Matthew's Gospel as a whole, but within the context of the sweep of Scripture's grand narrative. It fits well with the eschatological or prophetic understanding of the term, but it advances the concept beyond Christology (Jesus is the one to whom the Old Testament pointed) towards biblical theology (the Kingdom anticipated by the entire Old Testament revelation has arrived). The two factors that contribute to the prominence of a kingdom understanding are, firstly, the centrality of the kingdom in the Sermon on the Mount (directly below); and secondly, the partial parallel in Luke 16:16:

1. The centrality of the Kingdom of heaven or God in the Sermon on the Mount (Yarbrough 2012:113-115):

a. The Beatitudes are bookended by references to the Kingdom $(5: 3,10)$;

b. The beginning of the central section (5:17-20) makes it clear that the Kingdom remains in view, since disciples who relax the law will be called least in the Kingdom, and disciples who fail to exhibit greater righteousness will face exclusion from it;

c. Perhaps the central request of the Lord's Prayer is that God's Kingdom would come (6:10);

d. The Kingdom is to be the disciples' priority (6:33);

e. Entry into the Kingdom is in view at the Sermon's close where Jesus makes it clear that only those who do God's will receive entry into it (7:21).

The centrality of this concept must be brought to bear on Matthew 5:17. Isolating $\pi \lambda \eta \rho$ ó $\omega$ from the context of $\beta \alpha \sigma i \lambda \varepsilon i ́ \alpha$ results in much confusion in determining its nature:

2. The partial parallel in Luke 16:16 (Moo 1984:23).

Whatever the literary relationship between these passages, it is evident that both Matthew and Luke have salvation history in view: the time period of the law and the prophets has run its course on account of the preaching of the good news of the kingdom of God (cf. Bock 1996:1356). There are several parallels between these two passages (Table 1).

Two other factors also suggest their correspondence: firstly,

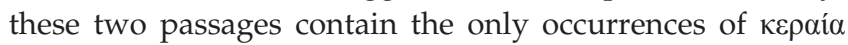
in the New Testament; and secondly, the only connections between vó $\mu$ o and $\beta \alpha \sigma \imath \lambda \varepsilon i ́ \alpha$ in the gospels occur in these two passages and Matthew 11:11-13.

There are, then, several connections between Matthew 5:17-19 and Luke 16:16-17, suggesting that the latter may shed some light on the former. When considering the possible senses by which $\pi \lambda \eta \rho$ ó $\omega$ could be understood, the links with the Lucan passage strongly suggest that it should be taken in a salvation-historical sense. What the law and the prophets pointed to, namely the coming kingdom of God, has arrived in Jesus and can therefore no longer be seen in precisely the same light.

All this argues that 'fulfilment' and 'kingdom' should be conceptualised together. When they are, fulfilment may be understood in terms of the eschatological arrival of

TABLE 1: Parallels between Matthew and Luke.

\begin{tabular}{|c|c|}
\hline Matthew 5:17-19 & Luke $16: 16-17$ \\
\hline 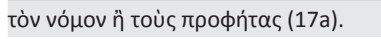 & O vó \\
\hline 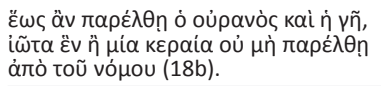 & 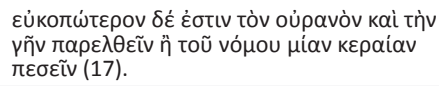 \\
\hline 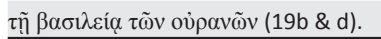 & 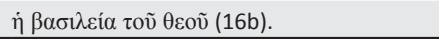 \\
\hline
\end{tabular}


God's promised reign. This salvation-historical reading of fulfilment enables one to avoid both a wooden adherence to, and an antinomian dismissal of the law. Fulfilment speaks of the sum total of all that the law and Prophets anticipated: God's Kingdom now inaugurated by God's King.

\section{Conclusion}

This article has asked what it means that Jesus fulfils the law and the prophets. It has attempted to answer by bringing literary, exegetical and theological considerations to bear upon its interpretation.

\section{Literary considerations:}

1. Matthew's structure places the focus on Jesus' authority.

2. Matthew's plot sees Jesus as the fulfilment of the story of Israel.

3. The Sermon on the Mount as a whole also places its focus on Jesus' authority.

4. The antitheses also focus on Jesus' authority and illustrate how the law is fulfilled.

5. The Kingdom of God forms the backdrop to the Sermon on the Mount, which has implications for how one understands the law and the prophets.

6. Finally, Matthew's concept of fulfilment has a salvationhistorical flavour, that is, what happened in Israel's history anticipated the actions displayed in Jesus' ministry.

These literary considerations provide extra weight to a salvation-historical reading of $\pi \lambda \eta \rho$ ó $\omega$ in 5:17.

\section{Further exegetical considerations}

1. The inclusion of the prophets indicates a predictive function is in view.

2. Matthew regularly employs $\pi \lambda \eta \rho$ ó $\omega$ to refer to the coming about of what was anticipated.

3. Matthew 11:13 illustrates that Matthew thought of the law as having a prophetic function. These constitute several of the regular arguments for the prophetic or eschatological view.

\section{Theological considerations}

Biblical theology, especially when understood redemptivehistorically, has highlighted the prominence of the concept of the Kingdom of God throughout Scripture as a theme that provides a form of unity amidst the diversity of Scripture. When we bring the respective insights of literary and theological exegesis to bear on Matthew 5:17, we see that what the law and prophets pointed towards, namely the arrival of the Kingdom of God, has come about in Jesus. The fulfilment to which Matthew refers, is the culmination of the biblical narrative in Jesus and the Kingdom he brings. Whilst this adds further support to the eschatological view of $\pi \lambda \eta \rho o ́ \omega$ in Matthew 5:17, it reinforces that our concept of fulfilment should take this kingdom emphasis into account, and therefore better be termed as 'salvationhistorical' than 'eschatological'. In short, Jesus fulfils the law and the prophets by bringing about the Kingdom they anticipated.

When one brings literary and theological findings to bear on the question of what it means that Jesus has fulfilled the law and the prophets, the importance of the Kingdom of God, not only the Person and Work of Christ, is highlighted in our conceptualisation of fulfilment.

\section{Acknowledgements}

I would like to acknowledge with gratitude the assistance offered by Prof. Francois Viljoen (North-West University) and Dr Peter Smuts (Bible Institute of South Africa) in the completion of the research necessary.

\section{Competing interests}

The author declares that he has no financial or personal relationship(s) that may have inappropriately influenced him in writing this article.

\section{Reference}

Allison, D.C., 1999, Sermon on the Mount, Crossroad, New York.

Arndt, W., Danker, F.W. \& Bauer, W., 2000, A Greek-English lexicon of the new testament and other early Christian literature [BDAG], University of Chicago Press, Chicago.

Banks, R., 1975, Jesus and the law in the synoptic tradition, Cambridge University Press, Cambridge. (Society for New Testament Monograph Series, 28).

Bartholomew, C.G., 2005, 'Biblical theology', in K.J. Vanhoozer (ed.), Dictionary for theological interpretation of the Bible, pp. 84-90, Baker Academic, Grand Rapids.

Bartholomew, C.G. \& Goheen, M.W., 2004, Drama of scripture, Baker Academic, Grand Rapids.

Beale, G.K., 2011, New testament biblical theology, Baker Academic, Grand Rapids.

Beasley-Murray, G.R., 1992, 'Kingdom of god in the teaching of Jesus', Journal of the Evangelical Theological Society 35(1), 19-30.

Blomberg, C.L., 2002, 'Interpreting old testament prophetic literature in Matthew: Double fulfilment', Trinity Journal 23, 17-33.

Bock, D.L., 1996, Luke 9:51-24:53, Baker Academic, Grand Rapids. (Baker Exegetical Commentary on the New Testament).

Carter, W., 1994, What are they saying about Matthew's Sermon on the Mount? Paulist Press, New York.

Chantry, W.J., 2008, 'The Christian and the moral law: Matthew 5:17-20', Banner of Truth 539(40), 56-64.

Charles, J.D., 2002, 'Garnishing with the "greater righteousness": The disciple's relationship to the law (Matthew 5:17-20)', Bulletin for Biblical Research 12(1), $1-15$.

Childs, B.S., 1992, Biblical theology of the old and newt testaments, Fortress Press, Minneapolis.

Davies, W.D., 1966, Sermon on the Mount, Cambridge University Press, London.

Davies, W.D. \& Allison, D.C., 1988, Critical and exegetical commentary on the gospel according to Saint Matthew: Matthew 1-7, vol. 1, T\&T Clark, Edinburgh. (International Critical Commentary).

Deines, R., 2008, 'Not the law but the Messiah: Law and righteousness in the gospel of Matthew - An ongoing debate', in D.M. Gurtner \& J. Noland, J. (eds.), pp. 53-84, Built upon the rock: Studies in the gospel of Matthew, Eerdmans, Grand Rapids.

Dunn, J.D.G., 2013, 'Law', J.B. Green (ed.), 2nd ed., Dictionary of Jesus and the gospels, pp. 505-515, InterVarsity Press, Downers Grove.

Eloff, M., 2008, 'A $\pi$ ó...̌̋ $\omega \varsigma$ and salvation history in Matthew's gospel', in D.M. Gurtner \& J. Noland, (eds.), pp. 85-107, Built upon the rock: Studies in the gospel of Matthew, Eerdmans, Grand Rapids.

Farmer, R., 1987, 'The kingdom of god in the gospel of Matthew', in W. Willis (ed.), Kingdom of god in 20th century interpretation, pp. 119-130, Hendrickson, Peabody.

France, R.T., 1989, Matthew Evangelist and teacher, Zondervan, Grand Rapids.

France, R.T., 2007, Gospel of Matthew, Eerdmans, Grand Rapids. (New International Commentary on the New Testament).

Gentry, P.J. \& Wellum, S.J., 2012, Kingdom through Covenant, Crossway, Wheaton.

Goldsworthy, G., 2012, Christ-centered Biblical Theology, Apollos, Nottingham.

Hagner, D.A., 1993, Matthew 1-13, Nelson, s.I. (Word Biblical Commentary, 33a). 
Hill, D., 1978, Gospel of Matthew, Oliphants, London. (New Century Bible).

Keener, C.S., 2009, Gospel of Matthew: A socio-rhetorical commentary, Eerdmans, Grand Rapids.

Kingsbury, J.D., 1989, Matthew: Structure, Christology, kingdom, Fortress Press, Minneapolis.

Kirk, J.R.D., 2008, 'Conceptualizing fulfilment in Matthew', Tyndale Bulletin 59(1), 77-98.

Kittel, G. \& Friedrich, G., (eds.), 1964, Theological Dictionary of the New Testament [TDNT], transl. G.W. Bromiley, Eerdmans, Grand Rapids.

Köstenburger, A.J., 2012, 'The present and future of biblical theology', Themelios 37(3), viewed 31 October 2014, from http://legacy.thegospelcoalition.org/ themelios/article/the_present_and_future_of_biblical_theology.

Loader, W., 2002, Jesus' attitude towards the law, Eerdmans, Grand Rapids.

Louw, J.P. \& Nida, E.A., 1996, Greek-English lexicon of the New Testament: Based on Semantic Domains, United Bible Societies, Stonehill Green.

Luz, U., 1989, Matthew 1-7, transl. W.C. Linss, T\&T Clark, Edinburgh.

Meier, J.P., 1991, Vision of Matthew, Crossroad, New York.

Meier, J.P., 2009, Marginal Jew: Law and love, vol. 4, Yale University Press, New Haven.

Moo, D.J., 1984, 'Jesus and the authority of the Mosaic Law', Journal for the Study of the New Testament 20, 3-49. http://dx.doi.org/10.1177/0142064X840060 2001

Moo., D.J., 1999, 'The law of Christ as the fulfillment of the law of Moses: A modified Lutheran view', in S.N. Gundry (ed.), Five views on law and gospel, pp. 319-376, Zondervan, Grand Rapids.

Nolland, J., 2005, Gospel of Matthew, Eerdmans, Grand Rapids, MI. (New International Greek Testament Commentary).

Pennington, J.T., 2007, Heaven and earth in the gospel of Matthew, Baker Academic, Grand Rapids. http://dx.doi.org/10.1163/ej.9789004162051.i-399

Pennington, J.T., 2008, 'Kingdom of heaven in the gospel of Matthew', Southern Baptist Journal of Theology 12(1), 44-51.

Powell, M.A., 1992, 'Plot and subplots of Matthew's gospel', New Testament Studies 38(2), 187-204. http://dx.doi.org/10.1017/S0028688500019858
Ridderbos, H., 1962, Coming of the Kingdom, transl. H. de Jongste, Presbyterian and Reformed, Grand Rapids.

Rosner, B.S., 2005, 'History of Salvation', in K.J. Vanhoozer (ed.), Dictionary for theological interpretation of the Bible, pp. 714-717, Baker Academic, Grand Rapids.

Ross, P.S., 2010, From the Finger of God, Christian Focus, Ross-shire.

Sanders, E.P., 1993, Historical figure of Jesus, Penguin Books, London.

Scobie, C.H., 2003, Ways of our God: An approach to biblical theology, Eerdmans, Grand Rapids.

Shapiro, J., 2007, Zapiro: Take two veg and call me in the morning, Jacana Media, Auckland Park.

Snodgrass, K.R., 1992. 'Matthew's understanding of the law', Interpretation 46(4), 368-378.

Talbert, C.H., 2004, Reading the Sermon on the Mount, Baker Academic, Grand Rapids. http://dx.doi.org/10.1177/002096439204600405

Thielman, F., 1999, Law and the new testament, Crossroad, New York.

Turner, D.L., 2008, Matthew, Baker Academic, Grand Rapids. (Baker Exegetical Commentary on the New Testament).

Viljoen, F., 2011. 'The foundational statement in Matthew 5:17-20 on the continuing validity of the law', In die Skriflig 45(2\&3), 385-407. http://dx.doi.org/10.4102/ ids.v45i2/3.20

Waltke, B.K., 2007, Old testament theology, Zondervan, Grand Rapids.

Waltke, B.K., 2012, 'Kingdom of god in the old testament: Definitions and story', in C.W. Morgan \& R.A. Peterson, (eds.), Kingdom of god, pp. 49-71, Crossway, Wheaton.

Wenham, D., 1979, 'Jesus and the Law: An Exegesis on Matthew 5:17-20', Themelios 4(3), 92-96.

Westerholm, S., 1992, 'Law in the Sermon on the Mount: Matt 5:17-48', Criswell Theological Review 6(1), 43-56.

Westerholm, S., 2006, Understanding Matthew, Baker Academic, Grand Rapids.

Wright, N.T., 1992, New Testament and the people of god, Fortress Press, Minneapolis.

Yarbrough, R.W., 2012, 'Kingdom of god in the New Testament: Matthew and Revelation' in C.W. Morgan \& R.A. Peterson (eds.), Kingdom of god, pp. 95-123, Crossway, Wheaton. 